\title{
Pengaruh Pelatihan, Kompensasi, Dan Disiplin Terhadap Kinerja Penyuluh Keluarga Berencana Di Kabupaten Bima
}

\author{
Safriatna $^{1}$, Hermanto ${ }^{2}$, Amalia kusuma Wardini ${ }^{3}$ \\ Program Pasca Sarjana, Universitas Terbuka \\ Email: achsafriatna@gmail.com
}

\begin{abstract}
Abstrak. Tujuan dari penelitian ini yaitu untuk mengetahui pelatihan, kompensasi, dan disiplin terhadap kinerja penyuluh keluarga berencana. Subyek yang diteliti adalah seluruh pegawai penyuluh keluarga berencana, mulai yang berpendidikan S-1 dan Diploma sampai S-2 dengan berbagai tingkatan masa kerja. Penelitian ini dilakukan di Kantor DP3AP2KB Kabupaten Bima. Adapun jumlah keseluruhan populasi yaitu 96 responden, dan adapun yang diambil menjadi sampel yaitu 54 responden. Variabel independen dalam penelitian ini yaitu pelatihan, kompensasi, dan disiplin, sedangkan yang menjadi variabel dependen dalam penelitian ini yaitu kinerja penyuluh keluarga berencana. Pengukuran variabel digunakan dengan pengukuran skala likert. Adapun analisis data yang digunakan adalah metode analisis deskriptif, dan analisis regresi berganda dengan melakukan uji asumsi klasik terlebih dahulu hasil analisis menunjukkan bahwa pelatihan, kompensasi, dan disiplin berpengaruh signifikan terhadap kinerja penyuluh keluarga berencana dengan nilai hasil analisis korelasi ganda antara $X_{1}, X_{2}$, dan $X_{3}$ dengan $Y$ sebesar 0,933 . variabel independen secara simultan berpegaruh terhadap perubahan variabel dependen adalah 69,5\%, sedangkan sisanya $30,5 \%$ dipengaruhi oleh variabel lain selain variabel independen $X_{1}, X_{2}$, dan $X_{3}$, dan disiplin merupakan variabel yang memiliki pengaruh paling dominan terhadap kinerja penyuluh keluarga berencana dengan nilai perbandingan t-test untuk $\mathrm{X}_{3}=10.890$ lebih besar nilainya daripada $\mathrm{X}_{1}=14.098$, dan $\mathrm{X}_{2}=6.081$.
\end{abstract}

Kata Kunci: Pelatihan, Kompensasi, Dan Disiplin, Kinerja Pegawai .

\section{PENDAHULUAN}

Keberadaan sumber daya manusia (SDM) dalam sebuah organisasi menjadi penentu utama terhadap tercapainnya tujuan organisasi. Dimana pencapaian tujuan organisasi sangat ditentukan oleh kinerja anggota yang ada di dalam organisasi. Kinerja organisasi adalah gambaran dari keseluruhan kinerja dari anggota yang ada dalam organisasi itu. Tamauka (2015) mengatakan kinerja merupakan cara kerja dalam suatu organisasi selama periode tertentu. Menurut Nurlaila (2010:71) kinerja adalah output dari proses kerja baik secara kualitas dan kuantitas selama melaksanakan fungsinya. Sementara dalam pendekatan manajemen, kinerja adalah kuantitas atau kualitas sesuatu yang dihasilkan atau jasa yang diberikan oleh seseorang yang telah melakukan pekerjaan (Luthans, 2005:165). Untuk mencapai kinerja yang tinggi diperlukan peningkatan profesionalisme aparatur sebagai pegawai atau anggota dalam organisasi berbagai cara diantaranya dengan melakukan pembinaan aparatur melalui program pelatihan. Swart dan Price (2005) pelatihan bagi seseorang yang bekerja dapat meningkatkan kualitas, efektifitas dan efisiensi kerja sehingga tidak terpaku pada teknologi, dan modal saja. Menurut Hasibuan (2010) pelatihan adalah suatu proses dimana orang-orang mencapai kemampuan tertentu untuk membantu mencapai tujuan organisasi. Oleh karena itu, proses ini terikat dengan berbagai tujuan organisasi. Pelatihan menyediakan para pegawai dengan pengetahuan yang spesifik dan dapat diketahui serta keterampilan yang digunakan dalam pekerjaan mereka saat ini. Menurut Pelatihan merupakan bagian dari investasi SDM (human investment) untuk meningkatkan kemampuan dan keterampilan kerja, dan dengan demikian meningkatkan kinerja pegawai. Pelatihan biasanya dilakukan dengan kurikulum yang disesuaikan dengan kebutuhan jabatan, diberikan dalam waktu yang relatif pendek, untuk membekali 
seseorang dengan keterampilan kerja. Hasil penelitian Halawi \& Haydar (2018) dan Ramya (2016) bahwa untuk meningkatkan kualitas kerja maka organisasi memprogram kegiatan pelatihan bagi karyawan sesuai dengan keterampilan khusus yang ingin dikembangkan. Pelatihan yang sesuai dengan kebutuhan untuk bekerja akan mendorong produktivitas dan kemajuan organisasi. Pada prinsipnya pelatihan merupakan rangkaian proses mengajarkan orang-orang agar memiliki ketrampilan dasar yang mereka butuhkan untuk menjalankan pekerjaan mereka.

Program pelatihan tidak cukup untuk menjamin produktivitas kerja dari pegawai harus dibarengi dengan faktor lain seperti kompensasi kerja. Mangkunegara (2010) mengemukakan secara mendalam mengenai apa yang dimaksud dengan kompensasi adalah segala sesuatu yang berhubungan dengan imbalan atas balas jasa yang diterima oleh seseorang setelah melakukan suatu pekerjaan baik dalam bentuk materi maupun non materi. Kompensasi juga berhubungan dengan insentif namun insentif menyangkut kompensasi berhubungan bayaran dengan produktivitas seseorang dalam menyelesaikan suatu pekerjaan biasa sesuai atau melebihi standar yang ditentukan. Tujuan mendasar dari semua program insentif adalah meningkatkan produktivitas para karyawan guna mencapai suatu keunggulan kompetitif. Menurut Ningtyas (2010) insentif adalah suatu penghargaan dalam bentuk uang yang diberikan oleh pihak pemimpin organisasi kepada karyawan agar mereka bekerja dengan motivasi yang tinggi dan berprestasi dalam mencapai tujuan-tujuan organisasi. Penelitian Murgianto dan Sulasmi (2016) dan Rizal dan Idrus (2014) menyimpulkan kompetensi kerja memiliki pengaruh positif dan signifikan terhadap motivasi dan kerja seseorang.

Dengan adanya kompensasi kerja diharapkan pegawai memiliki disiplin kerja yang baik. Disiplin merupakan bentuk pengendalian diri pegawai dan pelaksanaan yang teratur dan menunjukkan tingkat kesungguhan tim kerja di dalam sebuah organisasi (Simamora, 2006). Kedisiplinan dalam suatu instansi memegang peranan Jurnal Ilmu Sosial dan Pendidikan penting disamping faktor-faktor sumber daya manusia yang berkualitas dan yang berdedikasi tinggi untuk dapat mengembangkan suatu instansi karena sumber daya akan memberikan kemajuan dalam menentukan berhasil tidaknya rencana kerja yang telah dibuat atau yang telah direncanakan (Mangkunegara, 2011). Penelitian Syarkani (2017) dari hasil uji diketahui bahwa variabel disiplin kerja berpengaruh signifikan terhadap kinerja karyawan pada PT. Panca Konstruksi di Kabupaten Banjar. Peneliti lain Syaripah (2016) hasil penelitian menunjukkan bahwa karyawan secara rata-rata telah memiliki disiplin kerja yang baik dan disiplin kerja berpengaruh signifikan terhadap kinerja. Penelitian Simatupang dan Saroyeni (2018) bahwa perbaikan kinerja harus dimulai dari peningkatan kedisiplinan kerja. Artinya disiplin kerja mencerminkan kinerja seseorang.

Kinerja pegawai termasuk kinerja penyuluh keluarga berencana ditentukan oleh berbagai faktor seperti program pelatihan, kompensasi kerja, dan disiplin kerja. Hasil studi pendahuluan penelitian diketahui bahwa Penyuluh Keluarga Berencana Kabupaten Bima masih perlu ditingkatkan dimana pertumbuhan penduduk Kabupaten Bima yang begitu pesat merupakan akibat dari kelahiran yang tinggi. Penyuluhan Keluarga Berencana (KB) mempunyai fungsi untuk meningkatkan kepedulian masyarakat melalui pendewasaan usia perkawinan, pengaturan kelahiran, pembinaan ketahanan keluarga, peningkatan kesejahteraan keluarga serta mewujudkan norma kecil keluarga bahagia dan sejahtera. Secara ringkas ada beberapa permasalahan yang terjadi yang menunjukkan kinerja Penyuluh Keluarga Berencana Kabupaten Bima masih belum maksimal karana berdasarkan data Laporan Akuntabilitas dan Kinerja Pemerintah di Bidang Penyuluhan Keluarga Berencana (KB) Kabupaten Bima tahun 2015-2019, diketahui:

1. Realisasi Kebutuhan pelayanan KB yang tidak terpenuhi (unmet need) adalah $17,5 \%$ sehingga pencapaiannya adalah $58,63 \%$. Kebutuhan pelayanan $\mathrm{KB}$ yang tidak terpenuhi (unmet need) didefinisikan 
sebagai persentase wanita kawin yang tidak ingin punya anak lagi atau ingin menjarangkan kelahiran berikutnya, tetapi tidak memakai alat/cara kontrasepsi.

2. Angka kelahiran total (total fertility rate/TFR) per WUS (15-49 tahun) dan Persentase kebutuhan ber-KB yang tidak terpenuhi (unmet need) yang tidak mengalami perubahan. Hal ini menunjukan bahwa perlu upaya dan strategi yang kuat untuk mencapainya.

3. Tingkat putus pakai kontrasepsi tercapai $113,5 \%$ yang menunjukan masih jauh dari target sebelumnya.

Berdasarkan hasil analisis awal penyebab belum tercapainya beberapa target kinerja faktor penyebabnya antara lain belum optimalnya pelayanan KB di Kabupaten Bima yang disebabkan oleh:

1. Kompetensi kerja penyuluh yang belum memadai. Oleh karena itu diperlukan adanya kegiatan pelatihan-pelatihan bagi bidan dan dokter seperti pelatihan konseling dalam rangka keterampilan penyuluhan.

2. Penghematan/pemotongan anggaran penyuluhan yang dapat menyebabkan kompensasi yang tidak mencukupi bagi pelayanan penyuluhan.

Dapatlah dipahami adalah seuatu keharusan untuk dikaji secara mendalam mengenai komitmen dan kedisiplinan kerja karena dengan membaca tabel tersebut akan menunjukkan masih banyak yang dalam rutinitasnya tidak tertib dalam mematuhi kewajibannya sebagai pegawai penyuluhan. Oleh karena itu peneliti akan melakukan penelitian yang bertujuan:

1. Menganalisis pengaruh pelatihan kerja terhadap kinerja pegawai Penyuluh Keluarga Berencana Kabupaten Bima

2. Menganalisis pengaruh kompensasi terhadap kinerja pegawai Apakah pelatihan kerja berpengaruh terhadap kinerja pegawai Penyuluh Keluarga Berencana Kabupaten Bima

3. Menganalisis pengaruh disiplin kerja terhadap kinerja pegawai Apakah pelatihan kerja berpengaruh terhadap kinerja pegawai Penyuluh Keluarga Berencana Kabupaten Bima
4. Menganalisis variabel yang paling dominan pengaruhnya terhadap kinerja pegawai Penyuluh Keluarga Berencana Kabupaten Bima

\section{TINJAUAN PUSTAKA \\ Kinerja Pegawai}

Kinerja merupakan hasil secara kuantitas atau kualitas sebagai bukti atas kerja yang dilakukan oleh seseorang dalam bekerja (Luthans, 2011:165). Senada dengan itu, Mahsun (2013:141) mengatakan kinerja bisa dipahami mengenai gambaran umum tingkat pelaksanaan suatu kegiatan dalam mewujudkan tujuan organisasi yang tertuang dalam strategic planning suatu organisas. Mangkunegara (2011:67) mendefinisikan kinerja sebagai hasil keja secara kualitas dan kuantitas yang dicapai oleh seorang pegawai dalam melaksanakan tugasnya sesuai dengan tanggung jawab yang diberikan kepadanya. Wibowo (2011) menilai suatu hasil kerja yang dicapai seseorang dalam melakukan tugastugas yang dibebankan kepadanya didasarkan atas kecakapan, pengalaman, dan kesungguhan serta waktu.

Kemampuan seeseorang dalam bekerja dapat digolongkan sebagai kemampuan potensi dan orang yang memiliki potensi diatas rata-rata (IQ 110-120) harus mendapat perlakukan secara berbeda-beda seusai dengan potensi dan keahliannya terutama menyangkut penempatan kerja dan oleh karena itu proses pendidikan untuk jabatan memungkinkan bagi seseorang akan lebih produktif dalam bekerja karena dapat meningkatkan keterampilan. Kinerja seseorang tidak dapat diukur secara langsung melainkan harus diukur melalui gejala atau yang disebut dengan indikator. Hasibuan (2010:91) menguraikan beberapa indikator kinerja: (1) Kuantitas kerja menyakut seberapa jumlah pekerjaan yang telah dikerjakan dalam period tertetu. (2) Kualitas kerja menyangkut kehandalan orang dalam menyelesaikan pekerjaan sesuai dengan syarat tertetu. (3) Kerja sama yaitu kesediaan berupa kemauan dan kemampuan untuk membangun kebersamaan dalam keberagaman dalam menyelesaikan suatu pekerjaan. 


\section{Pelatihan Kerja}

Pelatihan merupakan sebuah proses mengajarkan pengetahuan dan keahlian tertentu, serta sikap agar karyawan semakin terampil dan mampu melaksanakan tanggungjawabnya dengan semakin baik, sesuai dengan strandar. Menurut Suwanto dan Donni (2011:117) pelatihan merupakan proses jangka pendek yang mempergunakan prosedur sistematis dan terorganisasi dimana pegawai non manajerial mempelajari pengetahuan dan keterampilan teknis dalam tujuan terbatas. Siagian (2008:175) mendefinisikan pelatihan adalah proses belajar mengajar dengan menggunakan teknik dan metoda tertentu secara konsepsional dapat dikatakan bahwa latihan dimaksudkan untuk meningkatkan keterampilan dan kemampuan kerja seseorang atau sekelompok orang. Mangkunegara (2011) mengatakan pelatihan merupakan upaya untuk memperbaiki penguasaan berbagai keterampilan dan teknik pelaksanaan kerja tertentu untuk kebutuhan sekarang dan untuk menyiapkan pegawainya siap memangku jabatan tertentu dimasa yang akan datang.

Menurut Bohlender (2013:101) ada beberapa metode dalam pelatihan tenaga kerja, antara lain: Pertama, Metode On The Job Training merupakan metode yang paling banyak digunakan perusahaan dalam melatih tenaga kerjanya. Para karyawan mempelajari pekerjaannya sambil mengerjakannya secara langsung. Kebanyakan perusahaan menggunakan orang dalam perusahaan yang melakukan pelatihan terhadap sumber daya manusianya, biasanya dilakukan oleh atasan langsung. Menurut Mangkunegara (2011:21) ada enam indikator pelatihan, yaitu sebagai berikut:

1. Tujuan: pelatihan merupakan tujuan yang ditetapkan, khususnya terkait dengan penyusunan rencana aksi (action play) dan penetapan sasaran, serta hasil yang diharapkan dari pelatihan yang akan diselenggarakan.

2. Sasaran: sasaran pelatihan harus ditentukan dengan kriteria yang terinci dan terukur (mesurabel).

3. Pelatih: mengingat pelatihan umumnya berorientasi pada peningkatan skill, maka

Jurnal Ilmu Sosial dan Pendidikan para pelatih yang dipilih untuk memberikan materi pelatihan harus benarbenar memilih kualifikasi yang memadai sesuai bidangnya, professional, dan kompeten.

4. Materi: pelatihan sumber daya manusia memerlukan materi atau kurikulum yang sesuai dengan tujuan pelatihan sumber daya manusia yang hendak dicapai oleh organisasi.

5. Metode: metode pelatihan akan lebih menjamin berlangsungnya kegiatan pelatihan sumber daya manusia yang efektif apabila sesuai dengan jenis materi dan kemampuan peserta pelatihan.

6. Peserta pelatihan: peserta pelatihan tentunya harus diseleksi berdasarkan persyaratan tertentu dan kualifikasi yang sesuai.

\section{Kompensasi Kerja}

Menurut Hasibuan (2010:118), kompensasi adalah semua pendapatan yang berbentuk uang, barang langsung atau tidak langsung yang diterima karyawan sebagai kompensasi atas jasa yang diberikan kepada perusahaan. Menurut Werther dan Davis (dalam Hasibuan, 2010:119), kompensasi adalah apa yang seorang pekerja terima sebagai balasan dari pekerjaan yang diberikannya. Baik upah per jam ataupun gaji periodik didesain dan dikelola oleh bagian personalia. Kompensasi merupakan pengeluaran dan biaya bagi perusahaan. Perusahaan mengharapkan agar kompensasi yang dibayarkan memperoleh kompensasi prestasi kerja yang lebih besar dari karyawan. Jadi, nilai prestasi kerja karyawan harus lebih besar dari kompensasi yang dibayar perusahaan, supaya perusahaan mendapatkan laba dan kontinuitas perusahaan terjamin. Jelaslah pentingnya masalah kompensasi ini untuk karyawan dan perusahaan. Yoder (dalam Hasibuan, 2010:117), mengemukakan "The payment made to member of work teams for their participation," artinya balas jasa membuat anggota tim kerja dapat bekerja sama dan berprestasi.

Menurut Wibowo (2011:348), kompensasi merupakan kontraprestasi terhadap penggunaan tenaga atau jasa yang 
telah diberikan oleh tenaga kerja. Wibowo juga mengatakan kompensasi merupakan jumlah paket yang ditawarkan organisasi kepada pekerja sebagai imbalan atas penggunaan tenaga kerjanya. Kompensasi merupakan salah satu faktor penting dan menjadi perhatian pada banyak organisasi dalam mempertahankan dan menarik sumber daya manusia yang berkualitas. Berbagai organisasi berkompetisi untuk memperoleh sumber daya manusia berkualitas, karena kualitas hasil pekerjaan ditentukan oleh kompetensi yang dimiliki sumber daya manusianya. Alasan ini membuat banyak organisasi mengeluarkan sejumlah dana yang relatif besar untuk mengembangkan sumber daya manusianya agar memiliki kompensasi sesuai kebutuhan (Rivai dan Sagala, 2013)

Kompensasi dipergunakan oleh pekerja untuk memenuhi kebutuhan-kebutuhan hidup. Besarnya kompensasi mencerminkan status, pengakuan, dan tingkat pemenuhan kebutuhan yang dinikmati oleh pekerja bersama keluarganya. Jika kompensasi yang diterima besar berarti tugas dan tanggung jawabnya juga semakin yang besar, statusnya semakin baik, dan pemenuhan kebutuhan semakin banyak pula. Menurut Dessler (2010) disinilah letak pentingnya kompensasi bagi pekerja sebagai seorang penjual tenaga (fisik dan pikiran). Tujuan pemberian kompensasi (balas jasa) antara lain meningkatkan kepuasan dan motivasi, disiplin dan stabilitas kerja. Menurut Sudarmanto (2012) komponen-komponen kompensasi terdiri dari:

1. Gaji adalah kompensasi dalam bentuk uang yang diterima pegawai sebagai konsekuensi dari kedudukannya sebagai seorang pegawai yang memberikan sumbangan tenaga dan pikiran dalam mencapai tujuan perusahaan;

2. Upah merupakan kompensasi financial langsung yang dibayarkan pada pegawai berdasarkan jam kerja, jumlah barang yang dihasilkan atau banyaknya pelayanan yang diberikan;

3. Insentif merupakan Kompensasi langsung yang dibayarkan kepada pegawai karena kinerjanya melebihi standar yang ditentukan. Insentif merupakan bentuk lain dari upah langsung diluar upah dan

gaji yang merupakan kompensasi tetap, yang biasa disebut kompensasi berdasarkan kinerja (pay for performance plan).

\section{Displina Kerja}

Kedisiplinan kerja merupakan kunci dari kesuksesan organisasi dalam menjalankan roda organisasinya. Jika orangorang dalam organisasi tidak memiliki atau kurang menerapkan kedisiplinan maka sudah dipastikan kinerja organisasi tersebut tidak produktif. Disiplin merupakan sebuah bentuk kepatuhan terhadap prosedur sehingga untuk mengoreksi atau menghukum bawahan yang telah melanggar peraturan merupakan bagian dari cara melacak kedisiplinan pegawai. Disiplin merupakan bentuk pengendalian diri pelaksanaan yang teratur dan menunjukkan tingkat kesungguhan tim kerja di dalam sebuah organisasi (Simamora, 2006:221). Rivai dan Sagala (2013) juga memberi komentar akademik mengenai disiplin kerja adalah suatu alat yang digunakan para manager untuk berkomunikasi dengan bawahan agar mereka bersedia untuk mengubah suatu perilaku serta sebagai suatu upaya untuk meningkatkan kesadaran dan kesediaan seseorang menaati semua peraturan dan norma-norma sosial yang berlaku.

Hasibuan (2010:193) mengatakan disiplin kerja berarti pegawai dalam melaksanakan tugasnya senantiasa menjunjung tinggi segala bentuk peraturan dan norma-norma sosial yang berlaku dalam organisasi. Disiplin berhubungan dengan akan kesadaran, keteladanan, dan adanya ketaatan pada peraturan. Artinya disiplin menjadi hal yang sangat urgen karena apapun bentuk dan jenis pola manajemen organisasi tidak akan mencapai tujuannya jika anggota tidak disiplin terhadap segala peraturan yang berlaku dalam organisasi. Ada beberapa faktor yang mempengaruhi displin kerja:

1. Jam kerja yang berkaitan dengan waktu masuk dan pulang kerja sehingga dapat menyebabkan orang-orang berkerja dalam organisasi.

2. Izin yang akan diberikan kepada seseorang untuk meninggalkan jam 
pekerjaannya harus didasari pada alasan yang dapat dipertanggungjawabkan.

3. Absensi ditempat kerja menyangkut kehadiran jam upacara, masuk dan pulang harus didasari pada objektivitas dalam mengisinya tanpa ada upaya manipulasi. Maksudnya yang tidak hadir tidak boleh dicantumkan sebagai pekerja yang aktif (Djarkasih, 2008:20).

Menurut Robinns (2008), terdapat tiga aspek disiplin kerja, yaitu:

1. Disiplin waktu diartikan sebagai sikap atau tingkah laku yang menunjukkan ketaatan terhadap jam kerja yang meliputi: kehadiran dan kepatuhan pada jam kerja, karyawan melaksanakan tugas dengan tepat waktu dan benar.

2. Disiplin peraturan taat pada peraturan maupun tata tertib yang tertulis dan tidak tertulis dibuat agar tujuan suatu organisasi dapat dicapai dengan baik. Untuk itu dibutuhkan sikap setia terhadap komitmen yang telah ditetapkan tersebut. Kesetiaan di sini berarti taat dan patuh dalam melaksanakan perintah dari atasan dan peraturan, tata tertib yang telah ditetapkan. Serta ketaatan dalam menggunakan kelengkapan pakaian seragam yang telah ditentukan organisasi

3. Disiplin tanggung jawab. Salah satu wujud tanggung jawab adalah penggunaan dan pemeliharaan peralatan yang sebaikbaiknya sehingga dapat menunjang kegiatan kantor berjalan dengan lancar. Serta adanya kesanggupan dalam menghadapi pekerjaan yang menjadi tanggung jawabnya.

\section{Hipotesis Penelitian}

1. Semakin Baik Kegiatan Pelatihan Kerja Maka Akan Semakin Baik Pula Kinerja Pegawai Penyuluh Keluarga Bencana Kabupaten Bima

2. Semakin Tinggi Kompensasi akan Berpengaruh Signifikan Terhadap Tingginya Kinerja Pegawai Penyuluh Keluarga Bencana Kabupaten Bima

3. Semakin Displin Pegawai Maka Akan Berpengaruh Signifikan Terhadap Peningkatan Kinerja Pegawai Penyuluh Keluarga Bencana Kabupaten Bima

Jurnal Ilmu Sosial dan Pendidikan

\section{METODE PENELITIAN}

Desain penelitian ini adalah penelitian yang mencai hubungan kausal (sebab-akibat) antara variabel independen dengan variable dependen. Hubungan sebab-akibat ini mencerminkan implikasi adanya atau berubahnya satu variabel menyebabkan atau berpengaruh pada variabel yang lain. Dengan kata lain desain dalam penelitian ini menjelaskan pengaruh parsial dan simultan variabel independen terhadap variabel dependen.

\section{Populasi dan Sampel Penelitian}

Populasi ada jumlah kesulurahan dari responden penelitian, dan yang menjadi populasi penelitian ini adalah seluruh Pegawai Penyuluh Keluarga Berencana Kabupaten Bima berjumlah 96 orang. Peneliti menggunakan semua populasi dalam penelitian ini yaitu seluruh pegawai penyuluh keluarga berencana (PKB) yang bekerja pada kantor Dinas Pemberdayaan Perempuan, Perlindungan Anak, Pengendalian penduduk dan Keluarga Berencana (DP3AP2KB) Kabupaten Bima yang berstatus ASN sebanyak 54 orang. Peneliti menggunakan alat atau instrumen berupa kuesioner penelitian dengan menggunakan skala likert (sikap, pendapat dan persepsi). Data dianalisis dengan menggunakan analisis regresi berganda. Regresi linier berganda yaitu model analisis untuk mengetahui pengaruh variabel independen dengan variabel dependen dengan menggunakan program SPSS 16, dan adapun model persamaan regresi:

$Y=\alpha+\beta_{1} X_{1}+\beta_{2} X_{2}+\beta_{3} X_{3}$

Keterangan:

$$
\begin{array}{ll}
\mathrm{Y} & =\text { Kinerja Pegawai } \\
\alpha & =\text { Konstan } \\
b X_{1} & =\text { Pelatihan Kerja } \\
b X_{2} & =\text { Kompenasasi Kerja } \\
b X_{3} & =\text { Disiplin Kerja }
\end{array}
$$

\section{HASIL PENELITIAN DATA VARIABEL Pelatihan}

Rata-rata memberi penilaian mengenai pelatihan berada pada kategori sangat baik 
atau sesuai dengan peningkatan kualitas kerja yaitu 40 orang atau $74 \%$, ada 12 orang atau $23 \%$ berada pada kategori sesuia/baik dan yang paling sedikit berada pada kategori cukup rendah, yaitu 2 orang atau $3 \%$.

\section{Kompensasi}

Menunjukkan rata-rata memberi penilaian mengenai kompensasi berada pada kategori tinggi atau sesuai yaitu 29 orang atau $54 \%$, ada 21 orang atau $39 \%$ berada pada kategori sangat tinggi dan yang paling sedikit berada pada kategori rendag cukup, yaitu 4 orang atau $7 \%$.

\section{Disiplin}

Menunjukkan rata-rata memberi penilaian mengenai disiplin kerja berada pada kategori tinggi sebanyak yaitu 29 orang atau 54\%, ada 25 orang atau $46 \%$ berada pada kategori sangat tinggi.

\section{Kinerja Pegawai}

Menunjukkan rata-rata memberi penilaian mengenai kinerja pegawai berada pada kategori tinggi yaitu 26 orang atau $48 \%$, ada 24 orang atau $43 \%$ berada pada kategori sangat tinggi dan ada 4 orang atau $7 \%$ berada pada ketegori cukup tinggi.

\section{Uji Persyarat Regresi}

Sebelum melakukan analisis regresi, baik analisis regresi linier sederhana maupun regresi linier berganda harus dipastikan apakah data-data yang akan dianalisis memenuhi persyaratan untuk dianalisis. Adapun peryaratan yang harus diuji yaitu:

\section{Linieritas \\ Tabel Hasil Uji Linearitas Kinerja dengan Pelatihan}

\begin{tabular}{|c|c|c|c|c|c|c|c|}
\hline \multicolumn{8}{|c|}{ ANOVA Table } \\
\hline & & & \begin{tabular}{c|} 
Sum of \\
Squares
\end{tabular} & df & \begin{tabular}{|c|} 
Mean \\
Square
\end{tabular} & $\mathrm{F}$ & Sig. \\
\hline \multirow{5}{*}{$\begin{array}{l}\text { Kinerja } \\
\text { Pegawai * } \\
\text { Pelatihan }\end{array}$} & \multirow{3}{*}{$\begin{array}{l}\text { Between } \\
\text { Groups }\end{array}$} & (Combined) & 1404.647 & 14 & 100.332 & 21.806 & .000 \\
\hline & & Linearity & 1255.574 & 1 & 1255.574 & 272.882 & .000 \\
\hline & & \begin{tabular}{|l|} 
Deviation \\
from \\
Linearity
\end{tabular} & 149.073 & 13 & 11.467 & 2.492 & .084 \\
\hline & \multicolumn{2}{|c|}{ Within Groups } & 179.445 & 39 & 4.601 & & \\
\hline & \multicolumn{2}{|l|}{ Total } & 1584.093 & 53 & & & \\
\hline
\end{tabular}

\section{Keputusan:}

Berdasarkan Tabel 4.13, taraf signifikan $0,084>0,05$ maka variabel pelatihan dengan dengan kinerja memiliki hubungan yang linier.

Tabel Hasil Uji Linearitas Kinerja dengan Kompensasi

\begin{tabular}{|c|c|c|c|c|c|c|c|}
\hline \multicolumn{8}{|c|}{ ANOVA Table } \\
\hline & & & $\begin{array}{l}\text { Sum of } \\
\text { Squares }\end{array}$ & df & $\begin{array}{c}\text { Mean } \\
\text { Square }\end{array}$ & F & Sig. \\
\hline \multirow{5}{*}{$\begin{array}{l}\text { Kinerja } \\
\text { Pegawai * } \\
\text { Kompensa } \\
\text { si }\end{array}$} & \multirow{3}{*}{$\begin{array}{l}\text { Between } \\
\text { Groups }\end{array}$} & (Combined) & 890.635 & 16 & 55.665 & 2.970 & .003 \\
\hline & & Linearity & 658.385 & 1 & 658.385 & $\begin{array}{r}35.12 \\
9 \\
\end{array}$ & .000 \\
\hline & & $\begin{array}{l}\text { Deviation } \\
\text { from } \\
\text { Linearity }\end{array}$ & 232.250 & 15 & 15.483 & .826 & .644 \\
\hline & \multicolumn{2}{|c|}{ Within Groups } & 693.457 & 37 & 18.742 & & \\
\hline & \multicolumn{2}{|l|}{ Total } & 1584.093 & 53 & & & \\
\hline
\end{tabular}

\section{Keputusan:}

Berdasarkan Tabel, taraf signifikan 0,644 > 0,05 maka variabel kompensasi dengan dengan kinerja memiliki pola hubungan linier.

Tabel Hasil Uji Linearitas Kinerja dengan Disiplin

\begin{tabular}{|l|l|l|c|r|r|r|r|}
\hline \multicolumn{7}{|c|}{ ANOVA Table } \\
\hline & & & $\begin{array}{c}\text { Sum of } \\
\text { Squares }\end{array}$ & \multicolumn{1}{c|}{$\begin{array}{c}\text { Mean } \\
\text { Square }\end{array}$} & \multicolumn{1}{c|}{ F } & Sig. \\
\hline $\begin{array}{l}\text { Kinerja } \\
\text { Pegawai * } \\
\text { Disiplin }\end{array}$ & $\begin{array}{l}\text { Between } \\
\text { Groups }\end{array}$ & (Combined) & 1204.702 & 14 & 86.050 & 8.846 & .000 \\
\cline { 3 - 9 } & & Linearity & 1101.213 & 1 & 1101.213 & 113.201 & .000 \\
\cline { 2 - 8 } & $\begin{array}{l}\text { Deviation from } \\
\text { Linearity }\end{array}$ & 103.488 & 13 & 7.961 & .818 & .638 \\
\cline { 2 - 8 } & Within Groups & 379.391 & 39 & 9.728 & & \\
\hline & Total & 1584.093 & 53 & & & \\
\hline
\end{tabular}

Keputusan:

Berdasarkan Tabel 4.15 taraf signifikan 0,638 > 0,05 maka variabel disiplin dengan dengan kinerja memiliki pola hubungan linier.

\section{Normalitas}

Uji normalitias Kolmogorof Smirnov merupakan bagian dari uji asumsi klasik yang bertujuan untuk mengetahui apakah nilai residual berdistribusi normal atau tidak, dimana model regresi yang baik adalah memiliki nilai residual berdistribusi normal. Dasar pengambilan keputusan:

1. Jika nilai signifikansi $>0,05$, maka nilai residual berdistribusi normal.

2. Jika nilai signifikansi $<0,05$, maka residual tidak berdistribusi normal. 
Tabel Hasil Uji Normalitas Kolmogorov-

\section{Smirnov Test}

\begin{tabular}{|c|c|c|c|c|c|}
\hline \multicolumn{6}{|c|}{ One-Sample Kolmogorov-Sminov Test } \\
\hline & & Pelatihan & Kompensasi & Disiplin & Kinerja \\
\hline \multicolumn{2}{|l|}{$\mathrm{N}$} & 54 & 54 & 54 & 54 \\
\hline \multirow[t]{2}{*}{ Normal Parameters ${ }^{\mathrm{a}}$} & Mean & 42.54 & 38.15 & 41.44 & 42.87 \\
\hline & \begin{tabular}{|l|} 
Std. \\
Deviation
\end{tabular} & 4.097 & 5.145 & 4.636 & 5.467 \\
\hline \multirow{3}{*}{$\begin{array}{l}\text { Most Extreme } \\
\text { Differences }\end{array}$} & Absolute & .115 & .122 & .164 & .182 \\
\hline & Positive & .108 & .080 & .164 & .182 \\
\hline & Negative & -.115 & -.122 & -.132 & -.128 \\
\hline \multicolumn{2}{|c|}{ Kolmogorov-SmirnovZ } & .842 & .897 & 1.205 & 1.335 \\
\hline \multicolumn{2}{|l|}{ Asymp. Sig. (2-tailed) } & .478 & .397 & .110 & .067 \\
\hline \multicolumn{2}{|c|}{ a. Test distribution is Normal. } & & & & \\
\hline & & & & & \\
\hline
\end{tabular}

\section{Keputusan:}

Berdasarkan data di atas, diketahui bahwa nilai signifikansi Asiymp.Sig (2-tailed) masing-masing variable yaitu pelatihan sebesar 0,474, kompensasi sebesar 0,379, disiplin sebesar 0,110 dan kinerja 0,067 lebih besar dari 0,05 maka sesuai dengan dasar pengambilan keputusan dalam uji normalitas Kolmogorof-Smirnov dapat disimpulkan bahwa data berdistribusi normal.

\section{Multikolinieritas}

Adapun hasil uji multikolinieritas dalam penelitian menggunakan bantuan SPSS 16 diketahui bahwa semua varibel penelitian tidak terjadi multikolineritas karena nilai tolerance lebih kecil dari 10 dan nilai VIF lebih besar dari 10 sebagaimana yang diperlihatkan pada tabel di bawah ini.

Tabel Ringkasan Hasil Uji Mulikolinieritas

\begin{tabular}{|c|c|c|c|c|}
\hline \multicolumn{5}{|c|}{ Coefficients ${ }^{\mathrm{a}}$} \\
\hline \multirow{2}{*}{\multicolumn{2}{|c|}{ Model }} & \multicolumn{3}{|c|}{ Collinearity Statistics } \\
\hline & & B & Tolerance & VIF \\
\hline \multirow[t]{4}{*}{1} & (Constant) & -11.118 & & \\
\hline & Pelatihan & .728 & .390 & 2.561 \\
\hline & Kompensasi & .479 & .568 & 1.498 \\
\hline & Disiplin & .591 & .408 & 2.450 \\
\hline & ndent Variab & & & \\
\hline
\end{tabular}

\section{Heterokadastisitas}

Pengujian untuk mendeteksi ada tidaknya heteroskedastisitas dilakukan dengan uji Glejser. Data dikatakan terbebas dari apabila secara statistik variabel bebas tidak berpengaruh signifikan terhadap variabel terikat (Absolut Ut (AbsUt). Keputusan jika sig. > 0,05 maka data tidak mengalami heteroskedastisitas.

Tabel Ringkasan Hasil Uji Heteroskedatisitas

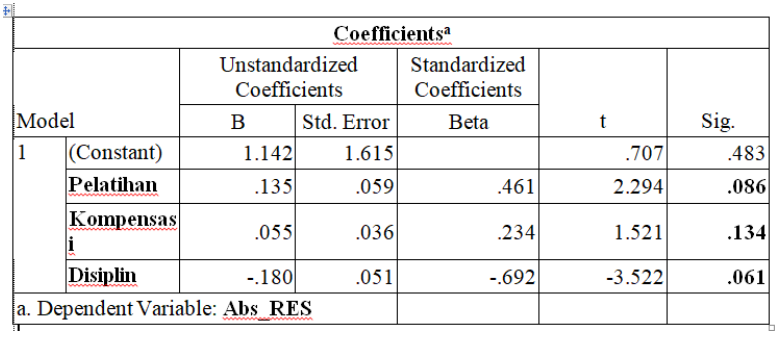

\section{Analisis Regersi Berganda Analisis Parsial}

Adapun hasil analisis regresi berganda mengenai pengaruh parsial masing-masing variabel bebas terhadap variabel terikat yang dapat dilihat pada tabel sebagai berikut:

Tabel Regresi Pengaruh Parsial

\begin{tabular}{|c|c|c|c|c|c|c|}
\hline \multicolumn{7}{|c|}{ Coefficients ${ }^{\mathrm{a}}$} \\
\hline & & \multicolumn{2}{|c|}{$\begin{array}{l}\text { Unstandardized } \\
\text { Coefficients }\end{array}$} & \multirow{2}{*}{$\begin{array}{c}\begin{array}{c}\text { Standardized } \\
\text { Coefficients }\end{array} \\
\text { Beta }\end{array}$} & \multirow[b]{2}{*}{$t$} & \multirow[b]{2}{*}{ Sig. } \\
\hline \multicolumn{2}{|c|}{ Model } & B & Std. Error & & & \\
\hline \multirow[t]{4}{*}{1} & (Constant) & 1.118 & 2.975 & & 3.737 & .000 \\
\hline & Pelatihan & 1.188 & .084 & .890 & 14.098 & .000 \\
\hline & Kompensasi & .685 & .113 & .645 & 6.081 & .000 \\
\hline & Disiplin & .983 & .090 & .834 & 10.890 & .000 \\
\hline & ndent Variab & inerja $\mathrm{Pe}$ & egawa1 & & & \\
\hline
\end{tabular}

Persamaan Regresi:

$\mathrm{Y}=\alpha(1.118)+\beta 1 \mathrm{X} 1(\mathbf{0 , 8 9 0 )}+\beta 2 \mathrm{X} 2$ $(0,645)+\beta 3$ X3 $(0,834)$

Tabel Penjelasan Persamaan Regresi

Simbol Penjelasan

\begin{tabular}{|c|l|}
\hline A & $\begin{array}{l}\text { Mengisyaratkan bahwa jika } \\
\text { tidak ada pelatihan, kompensasi } \\
\text { dan disiplin kerja dalam }\end{array}$ \\
& $\begin{array}{l}\text { pelaksanaan tugas maka kinerja } \\
\text { pegawai sebesar 1.118. }\end{array}$ \\
\hline$\beta_{1} \mathrm{X}_{1}$ & $\begin{array}{l}\text { Mengisyaratkan bahwa jika } \\
\text { pelatihan kerja bergeser sebesar }\end{array}$ \\
& satu saja maka akan menggeser \\
kinerja pegawai sebesar $0,890$. \\
\\
Besar pengaruh pelatihan \\
terhadap kinerja pegawai \\
sebesar $\left(0,890^{2} \times 100\right)=79,3 \%$ \\
dan sisanya dipengaruhi oleh \\
variabel lain. \\
\hline$\beta_{2} \mathrm{X}_{2}$ \\
$\begin{array}{l}\text { Mengisyaratkan bahwa jika } \\
\text { kompensasi kerja bergeser } \\
\text { sebesar satu saja maka akan } \\
\text { menggeser kinerja pegawai } \\
\text { sebesar 0,645. Artinya besar } \\
\text { pengaruh kompensasi terhadap } \\
\text { kinerja pegawai sebesar }\left(0,645^{2}\right. \\
\times 100)=41,6 \% \text { dan sisanya } \\
\text { dipengaruhi oleh variabel lain. }\end{array}$ \\
\hline
\end{tabular}




\begin{tabular}{|c|c|}
\hline$\beta_{3} X_{3}$ & $\begin{array}{l}\text { Mengisyaratkan bahwa jika } \\
\text { kepuasan kerja bergeser } \\
\text { sebesar satu saja maka akan } \\
\text { menggeser kinerja pegawai } \\
\text { sebesar } 0,834 \text {. Besar pengaruh } \\
\text { disiplin kerja terhadap kinerja } \\
\text { pegawai sebesar }\left(0,843^{2} \times 100\right) \\
=69,5 \% \text { dan sisanya } \\
\text { dipengaruhi oleh variabel lain. }\end{array}$ \\
\hline
\end{tabular}

Pengujian Hipotesis

Pengaruh Pelatihan Terhadap Kinerja Pegawai Penyuluh Keluarga Berencana Kabupaten Bima

Setelah dilakukan perhitungan diketahui bahwa t-hitung pelatihan sebesar 14.098 lebih besar dari t-tabel 2.004. Artinya hipotesis nihil (H0) ditolak dan hipotesis alternatif (Ha) bahwa "Pelatihan Kerja Berpengaruh Positif dan Signifikan Terhadap Kinerja Pegawai Penyuluh Keluarga Berencana Kabupaten Bima", diterima.

\section{Pengaruh Kompensasi Terhadap Kinerja Pegawai Penyuluh Keluarga Berencana Kabupaten Bima}

Setelah dilakukan perhitungan diketahui bahwa t-hitung kompensasi sebesar 6.081 lebih besar dari t-tabel 2.004. Artinya hipotesis nihil (H0) ditolak dan hipotesis alternatif (Ha) berbunyi "Kompensasi Kerja Berpengaruh Positif dan Signifikan Terhadap Kinerja Pegawai Penyuluh Keluarga Berencana Kabupaten Bima", diterima.

\section{Pengaruh Disiplin Kerja Terhadap Kinerja Pegawai Penyuluh Keluarga Berencana Kabupaten Bima}

Setelah dilakukan perhitungan diketahui bahwa t-hitung variabel displin kerja sebesar 10.890 lebih besar dari t-tabel 2.004 dengan taraf signifikan 0,00. Ini artinya hipotesis nihil (H0) ditolak dan hipotesis alternatif (Ha) yang berbunyi bahwa "Disiplin Kerja Berpengaruh Positif dan Signifikan Terhadap Kinerja Pegawai Penyuluh Keluarga Berencana Kabupaten Bima" dapat diterima.

\section{PEMBAHASAN}

Jurnal Ilmu Sosial dan Pendidikan

\section{Pengaruh Pelatihan Terhadap Kinerja Pegawai Penyuluh Keluarga Berencana Kabupaten Bima}

Hasil pengujian hipotesis penelitian diketahui bahwa pelatihan berpengaruh signifikan terhadap kinerja pegawai Penyuluh Keluarga Berencana Kabupaten Bima. Wilson (2012: 202) menyatakan bahwa pelatihan merupakan proses untuk meningkatkan kemampuan sumber daya manusia serta untuk memperbaiki keterampilan kerja pegawai untuk membantu tercapainya tujuan dari lembaga. Program-program yang ada dalam pelatihan akan memberi manfaat kepada lembaga dan pegawai itu sendiri. Hasil pengujian secara parsial variabel materi pelatihan berpengaruh signifikan terhadap variabel kinerja karyawan. Hasil penelitian Widijanto (2017) bahwa pelatihan kerja berpengaruh positif terhadap kinerja karyawan, motivasi kerja tidak berpengaruh positif terhadap kinerja karyawan, dan pelatihan kerja memiliki pengaruh yang lebih besar daripada motivasi kerja pada kinerja karyawan.

\section{Pengaruh Kompensasi Terhadap Kinerja Pegawai Penyuluh Keluarga Berencana Kabupaten Bima}

Kompensasi pegawai Penyuluh Keluarga Berencana Kabupaten Bima berdasarkan hasil analisis deskriptif diketahui tergolong cukup tinggi artinya pendapat dan insentif serta kelancaran dan ketepatan waktu pemberian gaji dan insentif tergolong tinggi karena ini akan berdampak pada kinerja pegawai. Hasil pengujian hipotesis menunjukkan pengaruh signifikan terhadap kinerja pegawai. Ini berarti kenaikan kompensasi akan memberikan dampak meningkatnya kinerja pegawai dan sebaliknya jika kompensasi yang diberikan kepada pegawai kurang maka kinerja pegawai akan rendah. Ini mendukung peneliti Dhermawan (2012) dan Potale (2015) bahwa kompensasi berpengaruh positif dan signifikan terhadap kinerja pegawai.

Pengaruh Disiplin Terhadap Kinerja Pegawai Penyuluh Keluarga Berencana Kabupaten Bima 
Hasil penelitian membuktikan bahwa disiplin kerja memiliki pengaruh signifikan terhadap kinerja pegawai Penyuluh Keluarga Kabupaten Bima. Disiplin merupakan perilaku kerja pegawai yang mencoba mengatasi kesalahan dan keteledoran yang disebabkan karena kurang perhatian, ketidakmampuan, dan keterlambatan. Disiplin kerja dapat dipahami sebagai suatu yang besar manfaatnya, baik bagi kepentingan organisasi maupun kelompok, bagi organisasi adanya disiplin kerja akan menjamin terpeliharanya tata tertib dan kelancaraan pelaksanaan tugas, sehingga diperoleh hasil yang optimal, sedangkan bagi pegawai akan diperoleh suasana kerja yang menyenangkan sehingga akan menambah semangat kerja dalam melaksanakan tugasnya.

Hasil penelitian ini mendukung penelitian Ariana (2013) bahwa perusahaan bisa lebih memperhatikan kemampuan karyawan, balas jasa terhadap karyawan, sanksi terhadap pelanggaran disiplin, pengawasan yang lebih ketat dalam upaya meningkatkan atau memperbaiki kinerja karyawan. Hal-hal tersebut membuktikan bahwa disiplin kerja merupakan faktor penting dalam meningkatkan kinerja karyawan. Dengan adanya disiplin kerja yang baik dari karyawan seperti datang tepat waktu, melaksanakan pekerjaan sesuai dengan apa yang telah ditetapkan oleh perusahaan, mentaati peraturan perusahaan maka akan dapat meningkatkan kinerja sesuai dengan target.

\section{KESIMPULAN DAN SARAN \\ Kesimpulan}

1. Semakin baik kegiatan pelatihan kerja yang diukti oleh pegawai maka akan semakin baik pulan dampaknya terhadap kinerja pegawai Penyuluh Keluarga Berencana Kabupaten Bima.

2. Jika pemberian kompensasi kerja tergolong tinggi maka akan berdampak positif dan signifikan terhadap peningkatan kinerja pegawai Penyuluh Keluarga Berencana Kabupaten Bima.

3. Sekamin disiplin pegawai dalam bekerja maka semakin baik pula kinerja pegawai

Jurnal Ilmu Sosial dan Pendidikan
Penyuluh Keluarga Berencana Kabupaten Bima.

\section{Saran}

1. Bagi Perwakilan BKKBN Propinsi Nusa Tenggara Barat agar dalam mengadakan pelatihan untuk melibatkan penyuluh $\mathrm{KB}$ dalam jumlah yang banyak.

2. Bagi Pelaksana pelatihan agar dalam proses pelatihan dapat mengunakan metode yang mudah dan cepat dimengerti oleh peserta.

3. Pemerintah Daerah agar lebih memperhatikan kondisi kinerja pegawai Penyuluh Keluarga Berencana mengingat tantangan yang semakin hari semakin besar maka dibutuhkan pelatihan kerja dalam rangka peremajaan dan penyesuain keterampilan, pemberian kompensasi yang tepat guna yang bertujuan untuk meningkatkan semangat pengabdian dan disiplin kerja pegawai.

4. Penentuan jumlah dan besarnya serta keadilan dalam pemberian kompensasi perlu diperhatikan karena kompensasi yang tinggi menurut persepsi pegawai akan berdampak besar terhadap kinerja pegawai.

5. Bagi pegawai Penyuluh Keluarga Berencana agar mempertahankan dan meningkatkan lagi semangat kerja terutama disiplin kerja agar menghasilkan kualitas dan kuantitas kerja sesuai dengan yang diharapkan.

\section{DAFTAR PUSTAKA}

Arikunto, S. 2012. Prosedur Penelitian. Jakarta: Rineka Cipta.

Ariana, I Wayan Tresna dan I Gede Riana. 2013. Pengaruh Kepemimpinan, Kompensasi dan Disiplin Kerja Terhadap Kinerja Karyawan Pada Hotel Cendana Resort \& Spa Ubud, Gianyar. E-Jurnal Manajemen Universitas Udayana, 2 (1).

Baharuddin dan Alhabsyi. 2014. Pengaruh Pelatihan, Kompensasi Dan Disiplin Kerja Terhadap Prestasi Kerja Karyawan (Studi Pada Kantor PT. PLN (Persero) Area Pelayanan dan Jaringan Malang). Jurnal Profit 
Volume 6 No. 62014. file:///C:/Users/User/Downloads/2381302-1-PB.pdf

Dessler, G. 2010. Manajemen Personalia. Jakarta: Prehalindo

Denny Triasmoko. 2014. Pengaruh Pelatihan Kerja Terhadap Kinerja Karyawan (Penelitian Pada Karyawan Pt Pos Indonesia (Persero) Cabang Kota Kediri). Jurnal Administrasi Bisnis (JAB)|Vol. 12 No. 1 Juli 2014| administrasibisnis.studentjournal.ub.ac .id.

https://media.neliti.com/media/publica tions/82871-ID-pengaruh-pelatihan-

kerja-terhadap-kinerj.pdf

Dhermawan. 2012. Pengaruh Motivasi, Lingkungan Kerja, Kompetensi, Dan Kompensasi Terhadap Kepuasan Kerja Dan Kinerja Pegawai di Lingkungan Kantor Dinas Pekerjaan Umum Provinsi Bali. Jurnal Manajemen, Strategi Bisnis, dan Kewirausahaan Vol. 6, No. 2 Agustus 2012.

file:///C:/Users/User/Downloads/22031-2669-1-10-20121105.pdf

Halawi dan Haydar (2018). Effects of Training on Employee Performance: A Case Study of Bonjus and Khatib \& Alami Companies. International Humanities Studies Vol. 5(2), June 2018 ISSN 2311-7796 Online.

Hasibuan. 2010. Manajemen Sumber Daya Manusia. Edisi Revisi. Jakarta : Bumi Aksara.

Handoko, Hanif. 2007. Manajemen Personalia dan Sumber Daya manusia. Yogyakarta: BPFE-UGM.

Husain. 2018. Pengaruh Disiplin Kerja Terhadap Kinerja Karyawan (Pada PT. Bank Danamon Tbk Cabang Bintaro. Jurnal Disrupsi Bisnis, Vol. 1, No. 1, Juli 2018 (1 - 15) @Prodi Manajemen Fakultas Ekonomi Universitas Pamulang. ISSN 2621 - 797X.

Luthans, F. 2011. Organizational Behavior. New York: McGraw-hill.

Mangkunegara. 2011. Manajemen Sumber Daya Manusia. Bandung : PT. Remaja Rosdakarya.

Jurnal Ilmu Sosial dan Pendidikan
Mahsun, M., Sulistiyowati, F., Purwanugraha, H.A. 2011. Akuntansi Sektor Publik. Edisi Ketiga. Yogyakarta. BPFE.

Mathis, R. L., Jackson, J. H., \& Valentine, S. R. (2016). Human resource management: Essential perspectives (7th ed.). Boston: Cengage Learning.

Murgianto dan Sulasmi. 2016. The Effects Of Commitment, Competence, Work Satisfaction On Motivation, And Performance Of Employees At Integrated Service Office Of East Java. International Journal of Advanced Research (2016), Volume 3, Issue -378-396

Mondy, R. Wayne. 2008. Human Resource Management. Di alih Bahasa oleh Bayu Airlangga, M.M. Edisi kesepuluh. PT Gelora Aksara Pratama

Nawawi. H. 2005. Manajemen Sumber Daya Manusia, Untuk Bisnis Yang Kompetitif. Gajah Mada University Press, Yogyakarta.

Ningtyas, Eka Diah. 2010. Remunerasi sebagai Penghargaan Kinerja Pegawai

Pemerintah

Nurlaila, 2010. Manajemen Sumber Daya Manusia I. Penerbit LepKhair

Panggabean, S.M, 2008. Manajemen Sumber Daya Manusia. Jakarta: Ghalia Indonesia

Ramya. 2016. The Effect Of Training On Employee Performance. International Journal of Scientific Research and Modern Education (IJSRME) ISSN (Online): $2455 \quad-\quad 5630$ (www.rdmodernresearch.com) Volume I, Issue I, 2016.

Rijalu dan Zewude (2014) The effect of compensation on employees motivation: In Jimma University academic staff. Basic Research Journal of Business Management and Accounts ISSN 2315-6899 Vol. 3(2) pp. 17-27 February 2014. http//www.basicresearchjournals.org

Rizal dan Idrus. 2014. Effect of Compensation on Motivation, Organizational Commitment and Employee Performance (Studies at Local Revenue Management in 
Kendari City). International Journal of Business and Management Invention. ISSN (Online): 2319 8028, ISSN (Print): 2319 - 801X $w w w$. ijbmi. org Volume 3 Issue 2 February 2014. PP. 64-79.

Rivai, Veithzal dan Sagala, Ella Jauvani. 2013. Manajemen Sumber Daya Manusia untuk Perusahaan dari Teori ke Praktek. Jakarta: PT. Raja Grafindo Persada.

Robbins, dan Judge. 2008. Perilaku Organisasi. Jakarta: Salemba empat.

Simanjuntak, P J. 2013. Manajemen dan Evaluasi Kinerja. Jakarta: Fakultas Ekonomi UI.

Simatupang dan Saroyeni. 2018. The Effect of Discipline, Motivation and Commitment to Employee Performance. IOSR Journal of Business and Management (IOSRJBM) e-ISSN: 2278-487X, p-ISSN: 2319-7668. Volume 20, Issue 6. Ver.

I. (June. 2018), PP 31-37 www.iosrjournals.org.

Simamora, Henry. 2009. Manajemen Sumber Daya Manusia. Yogyakarta: YKPN

Sudarmanto. 2012. Kinerja dan Pengembangan Kompetensi Sumber Daya Manusia. Yogyakarta: Pustaka Pelajar

Sutrisno, Edi. 2009. Manajemen Sumber Daya Manusia. Edisi Pertama. Jakarta: Kencana Prenada Media Group.

Syarkani. 2017. Pengaruh Disiplin Kerja Terhadap Kinerja Karyawan Pada PT. Panca Konstruksi di Kabupaten Banjar. Jurnal Ilmiah Ekonomi Bisnis, Vol 3, No 3, November 2017, hal 365 $-374$

Syaripah, N. 2016. Pengaruh Disiplin Kerja Terhadap Kinerja Karyawan Pada PT. HUME Sakti Indonesia. https://repository.widyatama.ac.id/xml ui/handle/123456789/7667?show=full.

Swart, J., Mann, C., Brown, S. and Price, A. 2005. Human Resource Development: Strategy and Tactics, Elsevier Butterworth-Heinemann. Publications. Oxford.
Suswanto dan Donni (2011). Manajemen SDM. Bandung: Alfabeta

Potale. 2015. Potale, Rocky. 2015. Pengaruh Kompensasi dan Stress Kerja Terhadap Kepuasan Kerja Karyawan Pada PT. Bank Sulut Cabang Utama Manado. Jurnal EMBA ISSN 23031174.Vol 3 No.1 (2015). http://ejournal.

unsrat.ac.id/index.php/emba/article/vie w/6567/6090. Diakses tanggal 1 November 2015. Hal $63-73$.

Pasolong, H. 2014. Teori Administrasi Publik. Bandung: Alfabeta

Tamauka, dan Christoffel Kojo dkk (2015). Pengaruh Konflik Peran, Konflik Kerja dan Stres Kerja Terhadap Kinerja Karyawan Pada PT. Air Manado. Fakultas Ekonomi dan Bisnis Universitas Sam Ratulangi Manado. Jurnal EMBA. Jurnalemba/victorlengkongkonflikkerj a.pdf. diakses 3 des 2017, Hal.90-98.

Unarajan, Dole. 2003. Manajemen Disiplin. Jakarta : Grasindo

Yuniarsih, T. 2011. Manajemen Sumber Daya Manusia. Alfabeta, Jakarta.

Wibowo. 2011. Manajemen Kinerja. Jakarta: Grafindo Persada

Widijanto, A. 2017. Pengaruh Pelatihan Kerja Dan Motivasi Kerja Terhadap Kinerja Karyawan Divisi Pemasaran di PT Sumber Hasil Sejati Surabaya. AGORA Vol. 5, No. 1, (2017). https://media.neliti.com/media/publica tions/53752-ID-pengaruh-pelatihankerja-dan-motivasi-te.pdf.

Wilson, Bangun. 2012. Manajemen Sumber Daya Manusia. Bandung: Erlangga. 